\title{
16 Between patriotism and nationalism
}

\author{
National identity in the education \\ policy of Law and Justice. Comments \\ on the 2017 education reform
}

\author{
Elżbieta M. Mach
}

\section{Introduction}

In his work Education. The Treasure Within, ${ }^{1}$ Jacques Delors emphasised the importance of education for building a community within European society, as well as shaping an attitude of tolerance and cooperation which would impact the spheres of the economy, politics and culture. The European Union (EU), on the basis of subsidiarity, has transferred to member states the responsibility to determine the shape of education, its contents, and the organisation of education systems in each country, by excluding educational policy from the exclusive competence of the EU. The Treaty of Lisbon confirmed this subsidiary direction in the development of the Union's educational policy; ${ }^{2}$ simultaneously emphasising respect for the provisions of the EU Charter of Fundamental Rights. ${ }^{3}$ The Union's aim is to foster the development of the European dimension in education through the teaching and dissemination of the languages of the member states, student and teacher mobility; the mutual recognition of diplomas and periods of study ${ }^{4}$ within the renewed EU programme for higher education; ${ }^{5}$ and the adaptation of competences shaped in the educational process to the needs of society and the labour market. Education policy has undergone significant change, from primarily consisting of exchanging information on the differences between national education policies, until 2020, when, based on the Lisbon Open Method of Coordination, it began relying on the voluntary cooperation of the member states, implementing guidelines, benchmarking, and sharing good practices. Today, it has become an area of common formulation of education objectives, joint activities and co-financing of education at the international level, ${ }^{6}$ based, among others, on European programmes such as Erasmus,$+{ }^{7}$ Europe for Citizens, ${ }^{8}$ Horizon $2020,{ }^{9}$ etc. All of them implement the educational priorities of the European Union, aimed at building a common space for education and research and European civil society. In 2006, the European Parliament and the Council published recommendations on key competences ${ }^{10}$ for lifelong learning. They include social ${ }^{11}$ and civic competences. Social competences equip individuals to participate in an effective and constructive way in social and working life, 
and particularly in increasingly diverse societies. They include intercultural competences. Civic competence equips individuals to fully participate in civic life, based on knowledge of social and political concepts and structures and a commitment to active and democratic participation. They are based on knowledge of the concepts of democracy, justice, equality and citizenship, and require full respect for human rights including equality as a basis for democracy, appreciation and understanding of differences between value systems of different religious or ethnic groups. ${ }^{12}$ Civic competence is directly related to a sense of belonging to one's locality and country, as well as the EU and Europe in general, and a respect for shared values (respect for democratic principles, support for social diversity and cohesion). ${ }^{13}$ The above-mentioned legal acts do not exhaust the entire catalogue of activities under the common education policy of the EU, but they indicate the direction of the educational policies of the member states.

\section{The role of national identity in the Prawo i Sprawiedliwość programme}

In the European Parliament, Law and Justice (Prawo i Sprawiedliwość, PIS), a party considered conservative-souverainist or national-populist, advocating conservative values and the doctrine of sovereignty, belongs to the European Conservatives and Reformists Party, ${ }^{14}$ formed by conservative parties.

According to the typology introduced by Paul Taggart and Aleks Szczerbiak, ${ }^{15}$ it can be considered a 'soft Eurosceptic' party, which does not negate the EU as such and does not postulate to leave its ranks, but opposes certain elements of the Community's functioning, which places it in partial opposition to the EU. In the typology developed by Petr Kopecký and Cas Mudde, we find PIS as a conservative cadre party having moderate acceptance of EU policies and classified as a Eurosceptic party among EU-pessimist parties.${ }^{16}$ However, Krzysztof Zuba definitely considers PIS a Euro-realist party, ${ }^{17}$ that is, one that partially accepts the actions of the Union and only rejects some of its facets. In its party programme documents, Prawo i Sprawiedliwość has declared itself a Euro-realist party that does not directly deny the significance of European integration and recognises its economic usefulness; while simultaneously criticising selected elements of its policy (e.g., the European community values, ${ }^{18}$ the Bologna system in higher education); ${ }^{19}$ and suspecting the EU of nefarious plans towards Poland (an attack on Polish sovereignty and prosperity, ${ }^{20}$ a plan to eliminate Polish fisheries, a destructive policy towards Polish railways or post, climate collusion, resignation from the use of veto, the ACTA agreement). ${ }^{21}$ PIS postulated strengthening the sovereignty and integrity of nation states and expressed its opposition to EU federalism:

We do not accept the uncontrolled erosion of the sovereignty of European homelands. We will defend our freedom resolutely by introducing the 
strongest legal barriers against the possibility of such practices against Poland. This is our Euro-realism, ${ }^{22}$

as per its 2014 programme. The EU and NATO were treated instrumentally, as a tool and place to serve Polish national interests, and not as participation in a community where common goals are pursued using jointly developed mechanisms and tools. ${ }^{23}$ According to the programme of the European Conservatives and Reformists Group, ${ }^{24}$ to which PIS belongs in the European Parliament, the family is recognised as the foundation of society: 'We will effectively defend the Polish national identity, tradition, culture, and the Polish model of life and customs against the emerging transnational tendencies to conduct risky cultural experiments'. ${ }^{25}$

From the very beginning of the party's existence, the main slogans of PIS included: nation, state, Church and decommunisation, as well as God, honour and fatherland, ${ }^{26}$ but - as Paweł Śpiewak noted - 'God means the Catholic Church, honour means decommunisation, and the fatherland means the Polish nation with a strong state over and behind it'. ${ }^{27}$ The national identity of a 'true Pole' was built on the basis of the martyrdom of the Polish nation, the wartime deeds of Poles, the actions of Solidarity in 1980, the union with the native land, native tradition and Catholicism. Decommunisation was an extremely popular slogan, which assumed not only settling accounts with the history of the Polish People's Republic, but above all exposing, ridiculing and excluding political opponents by showing their ties with 'commie rule'. In order to gather supporters, PIS developed a social welfare programme which won it the loyalty of the poorest social classes. ${ }^{28}$ It also leaned on populist rhetoric (by appealing to average recipients, primitivism and radical arguments that did not take into account reality, simplifying history, searching for 'the enemy of the people', intolerance of 'otherness', ${ }^{29}$ etc.), which became a way of achieving its ideological goals. ${ }^{30}$ Martyrdom as an identifying factor became obsolete in the times of long-lasting peace, the fall of communism in 1989, and after Poland joined the European Union. ${ }^{31}$ However, after the short-term euphoria brought about by Poland's new position in the international arena after 2004, PIS, starting from 2005, began putting forward the traditional idea of Polishness constructed on the foundation of combating enemies, threats and conspiracy theories, ${ }^{32}$ strengthening national phobias (Europhobia, anti-German sentiments, homophobia, etc.) and ridiculing or deprecating other European states and nations. ${ }^{33}$ A sense of power was established by emphasising sporting successes and building the illusion of economic strength. ${ }^{34}$

The longing for the 17th-century might of the Polish-Lithuanian Commonwealth focused foreign policy activities to the east, towards Vilnius and L'viv. ${ }^{35}$ The historical and identity policy has seen the Institute of National Remembrance rise through the ranks, an office tasked with documenting the actions of the German Third Reich, the Soviet Union and the People's Republic of Poland, and prosecuting crimes against the Polish Nation. ${ }^{36}$ PIS 
has chosen to not derive the European nature of Poland from the community of values enshrined in the Treaties ${ }^{37}$ and the EU Charter of Fundamental Rights but from the presence of Christianity and - above all - the Catholic Church in public life.

To this day, the Church is the holder and proclaimer of the moral teachings commonly known throughout Poland. (...) the status of the Catholic Church in our national and public life is exceptionally important ${ }^{38}(\ldots)$. The teachings of the Catholic Church, Polish tradition, and Polish patriotism have become intertwined in building the political identity of the nation. ${ }^{39}$

The rhetoric of PIS has polarised society around two main categories of identity: ${ }^{40}$ cultural (characteristic of people with secondary and higher education, living in cities, the identification factors included: Polish language, national culture, respect for state institutions and respect for the law) and ethno-religious identity (people with a low level of education, the elderly, inhabitants of rural areas and small towns, practising Catholics, supporters of patriarchal families, with a traditional perception of the role of women in both family and professional life. The Catholic faith and Polish origin constituted determining factors. Representatives of this group 'entrusted' the fate of their country and their families to Our Lady of Częstochowa and Jesus Christ, believing in divine providence rather than in the strength of their own work and reason. ${ }^{41}$ These people preferred uncritical obedience and submission to authority, strong-arm rule; they presented authoritarian political views, respecting the influence of religious authorities on how the law is interpreted. ${ }^{42}$

One of the factors creating the national identity of Poles has been patriotic education. Patriotism is most often defined as the designation of the concept of 'nation', equated with pride, respect, love, attachment and loyalty to the homeland, common beliefs, ideals, values and norms, attitudes and their manifestations, and putting the country's interests above one's own; ${ }^{43}$ it is a sense of a social and cultural bond, the awareness of being the guardian of independence, but also work; building appropriate interpersonal bonds of ethnic groups across the entire country, community and culture in general. ${ }^{44}$ Just like identity, patriotism is a variable construct 'ranging from local, parish, and regional patriotism, through national, state, and up to civic and civilizational ones' ${ }^{45}$ It can take the form of symbolic patriotism - based on an emotional attachment to the nation; or, blind patriotism - born out of a disturbed need for security, blind and uncritical loyalty, support for the political system and xenophobic rejection of any 'others' who might pose any potential danger. ${ }^{46}$ Looking at the PIS party programme documents, one can see that everything that is not Polish (including European integration) is treated as a threat to 'true Polishness', ${ }^{47}$ and such an understanding of the concept of nation, as described by Ernest Gellner, ${ }^{48}$ that might become the 
breeding ground for the concept of nationalism was used under the guise of slogans like 'patriotism' and 'true Polish identity'. Law and Justice defines the nation as 'a community of culture, language, historical experience, political tradition, civilizational values, as a community of fate' ${ }^{49}$ The PIS programme documents quoted, as well as educational documents defining the teaching content to be used in schools, are largely in line with the belief that 'the nation is the most important form of socialisation, and national identity is the most significant element of individual identity, combined with the imperative of putting national solidarity above all other relationships and obligations, and all that is national above all that is foreign or cosmopolitan'..$^{50}$

There is a perennial dispute among social scientists as to whether nationalism should be viewed in terms of ideology, as a doctrine, a value system, or a set of socio-political measures. The ongoing discussions prove that the concept of nationalism is not one-dimensional and remains subject to modelling, undergoing an endless evolution that allows it to adapt to the 'fluid reality' of the changing conditions of how states and nations are functioning. ${ }^{51}$ In its 'soft' form, nationalism concerns the bonds between the state, territory and culture, the emotional approach to the homeland, the natural relationship of man and society with the nation; it allows consistency between autonomy, unity, collective and (national) identity, and becomes an everyday identification phenomenon for the community. ${ }^{52}$ It is defined in relation to the state of consciousness of citizens, the idea according to which the functioning of the state is organised.$^{53} \mathrm{In}$ its aggressive form, "nationalism is associated with fanaticism, hostility, hatred and chauvinism. An extreme form of nationalism is found in chauvinism, which promotes racial, national, and ethnic discrimination, an uncritical attitude towards one's own nation, exaggeration of advantages and failure to perceive vices' ${ }^{54}$ In Poland, the concept of nationalism is placed in opposition to the concept of patriotism, with a thin line running between the two. Unreflective patriotism leading to uncritical national self-love, seeing one's own nation above others or depreciating those 'others', cultivating stereotypes, mythologising the past and idealising cultural heritage, while forgetting or denying the inglorious pages of history, can give lifeblood to nationalist attitudes and become a breeding ground for nationalist groups.

\section{Patriotic education, shaping national and European identity in light of the 2017 education reform}

In 2015, the Law and Justice government launched an educational reform, modifying both the curriculum guidelines at all educational levels and the structure of the school system. ${ }^{55}$ Politicians were well aware of the fact that education policy directly influences the modelling of social awareness, and that regulating the "textbook policy's6 would provide greater control over the teaching content provided to students. In its preamble, the Law on School Education ${ }^{57}$ declares that educational aims and tasks remain in line 
with the principles set out in the Constitution of the Republic of Poland, the guidelines contained in the Universal Declaration of Human Rights, the International Covenant on Civil and Political Rights, and the Convention on the Rights of the Child. It also emphasised the importance of patriotic education and schools' role in the development of democracy, tolerance, justice and freedom. ${ }^{58}$ The executive regulation ${ }^{59}$ to the Law set out the core curriculum for all stages of education in Polish schools.

The PIS education policy is consistent with the party programme declarations of both 2014 and 2019 and the party's Euro-realist image. According to them, also in the field of education, it aims to strengthen Polish traditionalism and conservatism, and shapes national identity in opposition to European identity, building on the historical memory of national martyrdom and the Catholic faith. The understanding of 'community' is based on the nation and the family ${ }^{60}$ with the latter being given a significant role in the process of education and upbringing, recommending 'cooperation with parents, various environments, organisations and institutions considered by parents as a source of essential values, in order to create conditions facilitating the development of identity' ${ }^{6}{ }^{61}$ Such a synergy between the school, the family, and the local environment would be advisable in civil society, however, taking into account the degree of disfunction ${ }^{62}$ and civic deficits in some Polish families ${ }^{63}$ (alcohol addiction, ${ }^{64}$ drug addiction, poverty, poor general education, lack of key competences ${ }^{65}$ almost fanatical folk Catholicism, ${ }^{66}$ patriarchalism, domestic violence, ${ }^{67}$ including sexual exploitation of children in families ${ }^{68}{ }^{6 t c}$.), one may be concerned about the positive impact of such a merger on the shaping of healthy patriotic and civic attitudes and preparing the young generation to function in an open and liberal Europe.

There is also a tendency in education to strengthen the role of the Catholic Church in public and political life. Students not attending religion classes were at times discriminated against by both their peers and teachers. ${ }^{69}$ The primacy of the Catholic religion taught at school over other denominations, an uncritical attitude towards the homeland, and providing students with a ready-made model of a 'true Pole', brings to mind illustrations from an old Italian primer from the $1930 \mathrm{~s}^{70}$ and the school curricula of the same period. $^{71}$

The 2014 PIS party programme declaration promised to unify teaching contents and prevent them from diverging in the future. ${ }^{72}$ The slogan of national identity, along with shaping patriotic attitudes, is already present in preschool education, as a result of which students should feel and be able to explain their belonging to the family and nation, be in a position to name and recognise values related to social behaviour, show respect for the homeland, perform and recognise the national anthem and its other symbols, know the name of their country and its capital, and recognise symbols related to Poland's individual regions buried in tales, proverbs, legends, and fairy tales. ${ }^{73}$ Primary school, which is the foundation of education, aims to introduce students to the world of values, among which the 
following are listed: 'dedication, cooperation, solidarity, altruism, patriotism and respect for tradition, showing models of behaviour and building social relations (...) strengthening the sense of individual, cultural, national, regional, and ethnic identity. (...) the sense of national identity, attachment to national history and traditions (...) $;^{74}$ as well as appropriate patriotic and civic upbringing understood 'in a broad sense - from the language used and behaviour, to social, moral and civic obligations'.$^{75}$ These major activities of Polish education are carried out by commemorating places of national remembrance, figures and events from the past, the most important national holidays and symbols of the state, as well as places of Catholic worship. ${ }^{76}$ There would be nothing wrong with such a model of patriotic upbringing if it were not for the fact that the core curriculum omits elements of multiculturalism, which provide students with a real picture of how diverse the world is. Regional education is dominated by folklore and Polish legends, while during geography classes students learn about Polish lands, their geographical and natural aspects. Patriotic education during history classes, which is a treasury of collective memory, includes 'The history of the homeland - filled with heroism and the daily toil of ancestors, full of courage and glory, but also tragedy and doubt, and even wickedness, (...) the values shaped include: homeland, nation, state, national and state symbols, patriotism, historical memory, truth, justice, kindness, beauty, freedom, solidarity, responsibility, courage, criticism, tolerance, identity, culture' ${ }^{77}$ National identity is built based on awakening love for the homeland by attaching students to the tradition and history of their country, glorifying national achievements, strengthening the sense of national dignity and pride. Historical education is divided into two worlds (often perceived by students as incoherent) - the history of Poland and universal history, covering the course of events in the world and in Europe. However, the two historical images are not presented equally. The strong emotional factor present in patriotic education instils in pupils the image of their homeland as a martyr among nations, with the historical role of a missionary, a country invaded and torn apart by the partitioning powers; Poles who were either oppressed or heroically lost their wars and uprisings; or else they had to go into eternal exile, dreaming about freedom and sacrificing their lives for it. Those who select national heritage have not attempted any degree of historical objectivity. In Polish schools, the history of other European countries is not taught with equal emotion. Topics such as the extermination of Jews, the inglorious deeds of Poles in Jedwabne, operation 'Danube' in 1968, and the occupation of Zaolzie, ${ }^{78}$ are ignored since they disfigure the beautiful image of a true Polish patriot.

Ministerial guidelines, and thus school textbooks, do not encourage exploring one's closest environment in search of ethnic or religious diversity. Where multiculturalism is commonplace, in borderlands or regions that have been inhabited by minorities for years, local schools and communities have learned to cooperate with 'aliens' who have largely become 'their own', ${ }^{79}$ and 
it is easier to show the diversity and heterogeneity of Polish society. However, in ethnically homogenous Polish and Catholic towns (especially in villages), ${ }^{80}$ each dissimilarity is treated as a social neoplasm, which must be removed as soon as possible so that it does not grow. The mono-ethnic and mono-religious vision of the nation is also finding its way into education.

Considering that the guidelines of the Ministry of Education are addressed to all citizens and regions of Poland, one should be worried about such a one-sided educational message, consolidating or creating xenophobic, homophobic, extremely national-Catholic attitudes, far from the assumptions of liberal democracy, the ideology of equality, and the acceptance of diversity. ${ }^{81}$ Poles often uncritically accept information from authorities (and school is one of them); they have trouble thinking independently, confronting complex and diverse information, posing non-standard theses and asking questions. What is important in the context of shaping identity and anti-totalitarian attitudes is that they are unable to interpret non-obvious meanings contained in statements, understand what they read, and argue for their position..$^{82} \mathrm{It}$ can therefore be assumed that some of them thoughtlessly accept the educational message amplified outside school by messages from the public media and church pulpits, perpetuating a Polonocentric worldview and the national Catholic self-portrait of Poles.

Already in its declaration of 2014, Law and Justice policy in the area of higher education aimed at returning to the system of integrated five-year studies, in place of the current system of two-cycle undergraduate and graduate studies, thus departing from the standard set out in the Bologna Declaration. ${ }^{83}$ The European dimension in Polish education is present in a rudimentary form. It seldom appears in the school curriculum and is presented without any particular emotional or practical value. In primary school, European topics appear when discussing Christmas customs in other EU countries, International Children's Day, or the anniversary of Poland's accession to the EU. ${ }^{84}$ These activities have no impact on permanently enriching students' identity with a European dimension. In the higher grades of primary school, one might expect that history or geography lessons would provide an opportunity to introduce Europeanistic contents, but here too patriotic topics reign, with a European context nowhere to be seen:

A well-established awareness of one's own values and roots as well as territorial identity, shaped during the process of learning about the geography of one's own region and home country, is the foundation that lets us understand other nations and cultures of the contemporary world without fear of losing one's own identity. ${ }^{85}$

Such educational guidelines are fully consistent with PIS's vision of Poland in the international arena, where the history and identity policy are an extremely important dimension of foreign policy and for the existence of Poland in the world. ${ }^{86}$ 


\section{Concluding observations}

Law and Justice educational policy remains consistent with the party's political programme, with calls for reform and accompanying actions ${ }^{87}$ being systematically implemented. The administrative and organisational reconstruction of the school system's structure has been carried out, Polish schools are constantly subsidised under European education measures, and attempts have been made to strengthen the status of teachers. There are plans to create self-education platforms, expand the structures of methodological support and counselling for young teachers and to reduce school bureaucracy. These changes provide an opportunity to strengthen the role of education in shaping society and training a workforce for the Polish economy. In this regard, schools under the PIS rule largely adhere (apart from the plans to depart from the Bologna system) to the assumptions of the European Union's education policy. Indeed, the Polish education system facilitates language teaching, student mobility, adapting education to the requirements of the labour market, etc.

What is worrying is the substantive part of the reforms, which - unfortunately - is very distant from the idea of a modern, open education that trains active, liberal, tolerant European citizens, remembering their roots and simultaneously ready to live their lives in a diverse European society. By abandoning pro-equality education, actual regional education, education about minorities, shaping acceptance for 'otherness', including national identity as an element of European identity, PIS's education policy does not follow the course set out by the education changes indicated in EU documents.

Reading the guidelines of the Ministry of Education on the core curriculum for Polish schools shows that, admittedly, the document does not officially break any accepted conventions and remains in line with the law; however, it ignores the context of Europe as a common area of the life, work and social existence of Poles. It assumes the dominance of Polonocentric patriotic education, a one-sided arrangement of educational contents, creating a belief in the superiority of one's own homeland over those of other people, an endeavour to maintain the conservative and traditional status quo of social life, for example, division of social roles, family model, gender roles. School curricula do not include education on gender ideology, equal rights for nonheteronormative people and religious or ethnic minorities. The context of the socio-cultural and religious diversity - not only of Europe, but also of the environment closest to the student, their 'local homeland' - is ignored.

Shaping national identity based on the idea of conflict, seeking enemies, martyrdom and a sense of threat locks out the possibility of peaceful cooperation with other minorities and nations, blurring the thin line between patriotic education and shaping national identity, and nationalist education in the spirit of intolerance to all 'otherness' and 'strangeness'. The result is a social consent to discriminating against every 'alien' who does not fit the pattern of a 'true Pole', and to excluding those who think differently from the 'majority in power'. Poles shaped in this way do not fit into modern Europe, 
where mobility, cultural diffusion as well as the creation of international partnerships and multicultural families are commonplace and normal; where there is no need to fight for national liberation, but there is a place for mutual respect for the obligations, rights and values recognised by treaties: ${ }^{88}$ respect for human dignity, freedom, democracy, equality, the rule of law, human rights, non-discrimination, tolerance, justice, solidarity, and equality between women and men; where national identity is one of the components of human identity, and European citizenship does not conflict with national citizenship. The political and social changes taking place in Poland under the influence of Prawo i Sprawiedliwość unfortunately raise the fear that Polish education is rolling towards nationalism like a snowball, taking over more and more areas of the state and the nation's existence.

\section{Notes}

1 Jacques Delors, Edukacja jest w niej ukryty skarb. Raport dla UNESCO Międzynarodowej Komisji do spraw Edukacji dla XXI wieku, (Stowarzyszenie Oświatowców Polskich Wydawnictwa UNESCO 1998).

2 'Treaty on the Functioning of the European Union (consolidated version)', (26 October 2012) Official Journal of the European Union, C326/47, Title XII, Article 165 https://eur-lex.europa.eu/legal-content/PL/TXT/PDF/?uri=CELEX:12012E/ TXT\&from $=$ PL accessed 20 June 2020.

3 Ibid., C 326/54.

4 'The Bologna Declaration' https://web.archive.org/web/20080211212119/http:// www.bologna-bergen2005.no/Docs/00-Main_doc/990719BOLOGNA_DECL ARATION.PDF accessed 12 August 2020.

5 'Communication from the Commission to the European Parliament, the Council, the European Economic and Social Committee and the Committee of the Regions on a Renewed EU Agenda for Higher education', COM (2017), 247 final https://eur-lex.europa.eu/legal-content/PL/TXT/PDF/?uri=CELEX:52017DC0 247\&from $=$ PL accessed 20 July 2020.

6 Magdalena Górowska-Fells, Zrozumieć edukacje w Europie. 20 lat Eurydice w Polsce, (Fundacja Rozwoju Systemu Edukacij 2017), 9.

7 Erasmus + began as Erasmus 1987-1994, then as Socrates 1995-1999, Socrates II 2000-2006, Lifelong Learning Programme 2007-2013, Erasmus + 2014-2020 www.frse.org.pl/ accessed 12 August 2020.

8 Europe for Citizens Programme https://eacea.ec.europa.eu/europe-for-citizens_en accessed 12 August 2020.

9 Horizon 2020 Programme https://ec.europa.eu/programmes/horizon2020/en accessed 12 August 2020.

10 'Recommendation of the European Parliament and of the Council of 18 December 2006 on Key Competences for Lifelong Learning, OJ L, 30 December 2006', $2006 /$ 962/EC https://eur-lex.europa.eu/legal-content/PL/TXT/PDF/?uri=CELEX:320 06H0962\&from $=\mathrm{EN}$ accessed 20 July 2020.

11 Ibid., 394/17. The competence includes: the ability to communicate constructively in different environments, to show tolerance, express and understand different viewpoints, to negotiate, and to feel empathy. It is based on an attitude 
of collaboration, assertiveness and integrity. Individuals should have an interest in intercultural communication and should value diversity and respect others, and be prepared both to overcome prejudices and to compromise.

12 Ibid., (n 10), 394/16.

13 Ibid., (n 10), 394/17.

14 European Conservatives and Reformists Party https://ecrparty.eu/ accessed 12 August 2020.

15 Paul Taggart and Aleks Szczerbiak, 'The Party Politics of Euroscepticism in EU Member and Candidate States', (Opposing Europe Research Network 2002) www. researchgate.net/profile/Aleks_Szczerbiak/publication/237536121_The_ Party_ Politics_of_Euroscepticism_in_EU_Member_and_Candidate_States/links/ 5534fb440cf2df9ea6a4122f.pdf 12 August 2020.

16 Petr Kopecký and Cas Mudde, 'The Two Sides of Euroscepticism. Party Positions on European Integration in East Central Europe', (2002), 3, European Union Politics, 3, 310-316.

17 Beata Kosowska-Gąstoł, 'Euroentuzjaści versus sceptycy - Układ sił politycznych w Parlamencie Europejskim VIII Kadencji oraz powyborcze scenariusze rozwoju' in Agnieszka Nitszke and Janusz Józef Węc, Podsumowanie VIII Kadencji Parlamentu Europejskiego. Wyzwania integracji europejskiej 2014-2019, (Księgarnia Akademicka 2019), 119-138.

18 President Andrzej Duda's public statements during the 2020 election campaign, for example, aimed at taking away the right to equality from LGBT people, denying gender ideology, abandoning the principle of solidarity during the migration crisis.

19 Program PIS 2014, 137 http://pis.org.pl/dokumenty accessed 10 July 2020.

20 Adam Balcer, Piotr Buras, Grzegorz Gromadzki, Eugeniusz Smolar, W zwarciu. Polityka europejska rzadu PIS, (Fundacja in S Batorego 2017), 5.

21 Program PIS 2014, (n 19), 22-25.

22 Ibid.

23 Ibid., 150.

24 European Conservatives and Reformists Party https://ecrparty.eu/ accessed 12 August 2020.

25 Program PIS 2014, (n 19), 157.

26 These slogans constitute flagship elements of the identification of nationalist organisations.

27 Paweł Śpiewak, 'Elektorat PIS w dwa lata po wyborczej klęsce' in Marek Migalski (ed), Prawo i Sprawiedliwość, Seria wydawnicza: Polskie Partie Polityczne, (Europejskie Centrum Edukacyjne 2010), 10.

28 PIS started, among others, the following social-welfare programmes: Family 500+ , school subsidy $300+$, free medicines for seniors 75+, the Mieszkanie+ ('Home+') programme, the Maluch+ ('Toddler+') programme, the Senior+ and Senior Vigor programme, and also lowered the retirement age.

29 Tadeusz Nowak, 'Demagogia i populistyczna propaganda w przekazie publicznym polskich partii opcji narodowo-prawicowej’ in Filip Pierzchalski and Bartosz Rydliński (ed), Autorytarny populizm w XXI wieku. Krytyczna rekonstrukcja, (Friedrich-Ebert-Stiftung, Przedstawicielstwo w Polsce 2017), 147-161.

30 Andrzej Ciążela, 'Czy tylko demagogia? Intelektualne i edukacyjne konteksty sukcesów prawicowego populizmu w Europie i USA' in ibid. 33-47.

31 Program PIS 2014, (n 19), 13. 
32 In the discourse, the politicians of the ruling party, headed by its president, Jarosław Kaczyński, along with the media coverage of the state television TVP, supported by the clerical Radio Maryja cooperating with the Prawo i Sprawiedliwość party, construct an image of an anti-Polish 'enemy' and utilise hate speech to shape the understanding of Polishness and what it means to be 'a true Pole'. Not caring about European values and numerous years of peaceful cooperation within an integrated Europe, using a mythologised historical memory of Poles, they include the following, among others, in the category of enemies of the homeland: the Germans - as the invader and occupier; The European Union - as a threat to Polish identity and Catholic values; refugees and immigrants - as a source of epidemiological plague and broadly understood 'aliens'; non-heteronormative persons - as dehumanised deviants; and even the native elite - as 'smarty pants' who are the enemies of truly Polish Catholic people. The state commission investigating the Smolensk tragedy used this event to build the myth of the attempted assassination and deliberate killing of passengers of the Tupolev Tu-154 M lux plane, on 10 April 2010. For many years, this myth had become a factor that united 'true Polish Catholics' during their monthly political-prayer-propaganda meetings held at the foot of the Smolensk monument. During Andrzej Duda's 2020 re-election campaign, even the pro-ecological youth movement calling for the fight against global warming was indicated as an enemy.

33 'Poland Continues Multi-Pronged Attack on French: "We Taught Them to Use Forks"' The Guardian, (London, 13 October 2016). A reference to the famous fork scandal, where the deputy Minister of National Defence said that it was Poles who taught the French how to use forks www.theguardian.com/world/2016/oct/ 13/poland-continues-multi-pronged-attack-on-french-we-taught-them-to-useforks accessed 20 July 2020.

34 The ruling party is very careful in selecting the identification attributes emphasised in social discourse, directing the attention of the average recipient mainly towards sporting successes. The 2018 Nobel Prize for Literature awarded to Olga Tokarczuk was not widely discussed either on national television or in the social rhetoric of government circles. The success of the Polish writer was not used as a factor of self-identification promoted by the ruling party. Perhaps it is because, in her work and other activities, the author raises issues that are inconvenient for PIS: equality of rights, restriction of civil liberties, discrimination, social justice, gender issues, issues concerning non-heteronormative people, reviving nationalisms, xenophobia, as well as nature and animal rights protection.

35 Program PIS 2014, (n 19), 132.

36 Ibid., 141.

37 European Union, EU treaties https://europa.eu/european-union/law/treaties_en accessed 20 July 2020.

38 Program PIS 2014, (n 19), 11.

39 Ibid., 14.

40 Sławomir Mandes, 'Polak-katolik' in Mirosława Marody, Joanna KoniecznaSałamatin, Maja Sawicka, Sławomir Mandes, Grażyna Kacprowicz, Krzysztof Bulkowski, and Jerzy Bartkowski (eds), Spoleczeństwo na zakręcie. Zmiany postaw i wartości Polaków w latach 1990-2018, (Wydawnictwo Naukowe SHOLAR 2019), $139-152$.

41 On 16 November 2016 at the Shrine of Divine Mercy in Krakow's Lagiewniki, in the presence of bishops and priests, the President of the Republic of Poland 
Andrzej Duda, representatives of the Polish government, with the participation of the faithful, Jesus Christ was crowned as king of Poland. Cf http://introniza cja.pl/; https://wiadomosci.gazeta.pl/wiadomosci/7,114883,21000510,tlumy-naintronizacji-jezusa-na-krola-polski-uroczystosc-trwa.html; www.newsweek.pl/ polska/intronizacja-jezusa-chrystusa-na-krola-w-krakowie/2vkxmwf accessed 10 July 2020.

42 Mandes, (n 40), 145-146.

43 'Patriotyzm' https://encyklopedia.pwn.pl/haslo/patriotyzm;3955049.html accessed 10 July 2020.

44 Janusz Gajda, 'Racjonalny patriotyzm jako antidotum skrajnego nacjonalizmu' in Jerzy Nikitorowicz (ed), Patriotyzm i nacjonalizm. Ku jakiej tożsamości kulturowej?, (IMPULS 2013), 50-53.

45 Jerzy Nikitorowicz, 'Dylematy patriotyzmu, nacjonalizmu i ustawicznie kształtującej się tożsamości. Wprowadzenie do książki’ in Jerzy Nikitorowicz (ed), Patriotyzm i nacjonalizm. Ku jakiej tożsamości kulturowej?, (IMPULS 2013), 16.

46 Mirosława Czerniawska, 'Patriotyzm - jak znaleźć mu miejsce w mentalności społeczeństwa?’ in Jerzy Nikitorowicz (ed), Patriotyzm i nacjonalizm. Ku jakiej tożsamości kulturowej?, (IMPULS 2013), 76-86.

47 Program PIS 2019, 14 http://pis.org.pl/dokumenty accessed 10 July 2020.

48 Ernest Gellner, Narodyinacjonalizm,(Państwowy Instytut Wydawniczy1991), 72-74.

49 Program PIS 2019, (n 47), 12.

50 'Nacjonalizm' https://encyklopedia.pwn.pl/haslo/nacjonalizm;3945094.html accessed 10 July 2020.

51 Zygmunt Bauman, Plynna nowoczesność, (Wydawnictwo literackie 2006). A reference to the concept defined by Zygmunt Bauman as 'liquid modernity', characterised by an individual's uncertainty in the face of the permanent deconstruction of meanings, the vagueness and episodic nature of beings, and the lack of stability that gives a sense of security.

52 Andrzej Nikitorowicz, 'Nacjonalizm w warunkach demokracji' in Jerzy Nikitorowicz (ed), Patriotyzm i nacjonalizm. Ku jakiej tożsamości kulturowej?, (Impuls 2013), 87-105.

53 Marek Waldenberg, Narody zależne i mniejszości narodowe w Europie ŚrodkowoWschodniej: dzieje konfliktów i idei, (Wydawnictwo Naukowe PWN 2000), 39.

54 Nikitorowicz, (n 45), 19.

55 EACEA, 'Organisation of the Educational System and of its Structure' https:// eacea.ec.europa.eu/national-policies/eurydice/content/organisation-education-sys tem-and-its-structure-56_en accessed 28 July 2020.

56 From the school year 2014/2015, schools could use free textbooks provided by the Ministry of National Education. The textbook reform was to be completed by 1 September 2017, when free textbooks were made available for all primary and middle school grades. See also: List of MEN textbooks. https://podreczniki.men. gov.pl/ accessed 1 July 2020.

57 The Law of September 7, 1991 on School Education. Prepared on the basis of: Journal of Laws of 2015, item 2156, of 2016, item 35, 64, 195, 668, 1010, (Chancellery of the Sejm p. 1/402 of 3 October 2016).

58 Ibid., 1/402 'Education in the Republic of Poland is the common good of the entire society; it is guided by the principles contained in the Constitution of the Republic of Poland, as well as the guidelines enshrined in the Universal Declaration of Human Rights, the International Covenant on Civil and Political Rights, and the 
Convention on the Rights of the Child. Teaching and upbringing - with respect for the Christian system of values - is based on universal ethical principles. Education and upbringing serve to develop young people's sense of responsibility, love for the homeland and respect for Polish cultural heritage, while being open to the values of the cultures of Europe and the world. School should provide each student with the conditions necessary for their development, prepare them to fulfil family and civic obligations based on the principles of solidarity, democracy, tolerance, justice, and freedom'.

59 Regulation of the Minister of National Education of 14 February 2017 on the core curriculum for preschool education and the core curriculum for general education in primary schools, incl. for pupils with moderate and severe intellectual disability, and for general education in stage I sectoral vocational schools, general education in special schools preparing for employment, and general education in post-secondary schools, Journal of Laws of the Republic of Poland, Warsaw 24 February 2017, item 356.

60 Program PIS 2014, (n 19), 8.

61 Regulation of the Minister of National Education, (n 59), 3/12, 13.

62 'Family Dysfunctions. Statystyka policji' https://statystyka.policja.pl/st/wybranestatystyki/przemoc-w-rodzinie accessed 28 July 2020.

63 Małgorzata Izabela Słomczyńska, Patologie społeczne $w$ kontekście kryzysu współczesnej rodziny, e-ISSN 2392-2656, (Resocjalizacja polska no. 8/2014).

64 'Family Dysfunctions' http://parpamail.nazwa.pl/parpa_en/; https://serwisy.gazet aprawna.pl/zdrowie/artykuly/1430648,alkohol-uzaleznienie-alkoholizm-eksperci. html accessed 28 July 2020.

65 European Commission, 'Key Competences and Basic Skills' https://ec.europa. eu/education/policies/school/key-competences-and-basic-skills_en accessed 20 July 2020.

66 Adam Szostkiewicz, Dokąd zmierza polski Kościót? (Polityka 2017) www.polityka. p1/tygodnikpolityka/kraj/1708450,1,dokad-zmierza-polski-kosciol.read accessed 20 July 2020.

67 Ewa Jarosz, 'Przemoc w wychowaniu w Polsce. Obraz problemu na tle społecznej aprobaty, opinii na temat działań, oraz deklaracji rodziców', Monitoring Rzecznika Praw Dziecka, Uniwersytet Śląski 2017 www.childrenatrisk.eu/nonviolence/wp-content/uploads/sites/3/2017/12/Jarosz-wyniki-bada\%C5\%84krajowa-konsultacja-CBSS.pdf accessed 20 July 2020.

68 Ewa Jarosz and Anna Nowak, Dzieci ofiary przemocy w rodzinie. Raport Rzecznika Praw Dziecka, (Warszawa 2012).

69 Renata Kim and Anna Szulc, Edukacja w stużbie Kościoła. Szkoła religijna, (Newsweek 20/2018), 21-24.

70 Dina Bucciarelli Belardinelli, Sillabario e piccole letture, (La libreria dello Stato A X [1932]).

71 Elżbieta M Mach, Cele i treści kształcenia w związu z integracja europejska na przykładzie edukacji wczesnoszkolnej we Włoszech $i$ w Polsce, (Wydawnictwo Uniwersytetu Jagiellońskiego 2017), 87-121.

72 Program PIS 2014, (n 19), 130.

73 Regulation of the Minister of National Education, (n 59), 5-6.

74 Ibid., 11, 14.

75 Program PIS 2014, (n 19), 131.

76 Regulation of the Minister of National Education, (n 59), 15. 


\section{Elżbieta M. Mach}

77 Ibid., 22.

78 Kamil Janicki and Rafał Kuzak, '10 faktów z polskiej historii, o których wolelibyśmy nie pamiętać’ https://ciekawostkihistoryczne.pl/2014/07/28/10-wydar zen-z-polskiej-historii-o-ktorych-wolelibysmy-nie-pamietacl accessed 10 July 2020; Bronisław Tumiłowicz, 'Czego najbardziej wstydzimy się w historii Polski' www.tygodnikprzeglad.pl/czego-najbardziej-sie-wstydzimy-historii-polski/ accessed 10 July 2020.

79 Jerzy Nikitorowicz, Pogranicze, tożsamość, edukacja międzykulturowa, (Trans Humana 1995).

80 In large agglomerations the situation is somewhat different. It is easier to be anonymous there, and all kinds of diversity are part of the urban social landscape.

81 Such modelling is taking place implicitly and informally as part of the hidden curriculum, although it can be assumed that it is not happening unintentionally. From the above-mentioned analysis of the PIS programme from 2019 'The Polish Model of the Welfare State', one can get the impression that these actions are completely consistent with the vision of the ruling party.

82 Program międzynarodowej ceny umiejętności uczniów. Wyniki badania PISA 2015 w Polsce, (OCDE, IBM, MEN 2017).

83 Program PIS 2014, (n 19), 137.

84 Regulation of the Minister of National Education, (n 59), 39.

85 Ibid., 24.

86 Program PIS 2014, (n 19), 142.

87 Ibid., 2019, (n 47), 12.

88 'Consolidated versions of the Treaty on European Union and the Treaty on the Functioning of the European Union', Journal of Laws UE C326/1, 26.10.2012 https://eur-lex.europa.eu/legal-content/PL/TXT/?uri=uriserv:OJ.C_ .2012.326.01.0001.01.POL\&toc=OJ:C:2012:326:TOC accessed 20 July 2020;

EU Charter of Fundamental Rights, Journal of Laws EU 326/391, 2012/C 326/ 02 https://eur-lex.europa.eu/legal-content/PL/TXT/?uri=uriserv:OJ.C_.2012.326. 01.0391.01.POL\&toc=OJ:C:2012:326:TOC accessed 20 July 2020. 